\title{
The behaviour of thiomolybdates in in vitro systems
}

\author{
BY K. M. WEBER, D. D. LEAVER AND A. G. WEDD \\ School of Agriculture and Department of Inorganic and Analytical \\ Chemistry, La Trobe University, Bundoora 3083, Australia
}

(Received 2 August 1978 - Accepted 30 October 1978)

\begin{abstract}
The stability of potassium tetrathiomolybdate was studied in vitro using solutions with molybdenum, hydrogen ion and phosphate concentrations similar to those normally found in the rumen. Under these conditions $\mathrm{K}_{2}\left[\mathrm{MoS}_{4}\right]$ hydrolysed rapidly and as a result the solution contained $\left[\mathrm{MoS}_{4}\right]^{2-}$, $\left[\mathrm{MoOS}_{3}\right]^{2-}$, $\left[\mathrm{MoO}_{2} \mathrm{~S}_{2}\right]^{2-}$, [HS]- and $\mathrm{H}_{2} \mathrm{~S}$ in equilibrium. In view of this hydrolysis, in vivo studies of thiomolybdate on copper metabolism of sheep should not exclude the possibility that either sulphide or molybdate is responsible for any observed effect.
\end{abstract}

For some considerable time dietary molybdenum and sulphur have been known to interfere with the absorption and metabolism of copper in sheep (Dick, I953) but the precise mechanism for this interaction is not yet fully understood (Suttle, 1974a). One plausible explanation is that molybdenum or sulphur or both combine with $\mathrm{Cu}$ to produce an insoluble $\mathrm{Cu}$ complex which is poorly absorbed from the intestine. It has been shown for example that with increases in the dietary intake of Mo and $S$ the rumen sulphide concentration may change (Gawthorne \& Nader, 1976) resulting in enhanced production of insoluble copper sulphide (Mills, I960; Suttle, 1974b). On the other hand, Dowdy \& Matrone (I968) have demonstrated in vitro production of a $\mathrm{Cu}-\mathrm{Mo}$ compound which has also exhibited limited $\mathrm{Cu}$ availability in vivo.

Mo and S may also react to form thiomolybdates in the rumen and it has been proposed that these may combine with $\mathrm{Cu}$ to produce insoluble copper thiomolybdates (Dick et al. I975). In order to test the hypothesis that these thiomolybdates influence $\mathrm{Cu}$ metabolism in vivo, potassium tetrathiomolybdate was prepared for use in experiments designed to examine its effect on the turnover of ${ }^{64} \mathrm{Cu}$ in sheep (Weber et al. 1976). Preliminary experiments however, indicated a rapid hydrolysis of $\left[\mathrm{MoS}_{4}\right]^{2-}$ in aqueous solutions. Hence, before commencing in vivo experiments, a chemical study was undertaken to determine the behaviour of these compounds in aqueous solutions over a range of in vitro conditions including those resembling the rumen environment and treatment media.

\section{EXPERIMENTAL}

Orange, crystalline $\mathrm{K}_{2}\left[\mathrm{MoS}_{4}\right]$ was synthesized (Krüss, I884), characterized, and stored under nitrogen to prevent hydrolysis. Electronic spectral measurements were made on a Varian series 634 spectrometer using matched quartz cells of path lengths 0.5 , I and ro mm.

Equilibrium studies were carried out for initial Mo concentrations in the range $10^{-3}-$ $2.4 \times 10^{-5} \mathrm{M}$ in water (doubly distilled from glass) whose $\mathrm{pH}$ had been adjusted with either potassium hydroxide or sulphuric acid or buffered with $0.2 \mathrm{M}$-potassium phosphate. The solutions were prepared by rapid dissolution of samples of $\mathrm{K}_{2}\left[\mathrm{MoS}_{4}\right]$ followed by transfer to closed spectral and $\mathrm{pH}$ cells, with a minimum vapour gap.

Relevant spectral characteristics of various thiomolybdate ions in the range $300-600 \mathrm{~nm}$ are presented in Table I. The electronic spectra of the ions $\left[\mathrm{MoO}_{4-n} \mathrm{~S}_{n}\right]^{2-}(n=0-4)$ have been 
Table I. Spectral characteristics of thiomolybdate ions (Stiefel, I977)

$\begin{array}{ccc}\text { Ion } & \begin{array}{c}\text { Absorption maxima } \\ (\mathrm{nm})\end{array} & \begin{array}{c}\text { Extinction coefficient } \\ (1 / \mathrm{mol} \text { per mm })\end{array} \\ {\left[\mathrm{MoS}_{4}\right]^{2-}} & 467 & 1300 \\ & 317 & 1700 \\ {\left[\mathrm{MoOS}_{8}\right]^{2-}} & 465 & 230 \\ & 392 & 870 \\ & 316^{*} & 660 \\ {\left[\mathrm{MoO}_{8} \mathrm{~S}_{8}\right]^{3-}} & 394 & 300 \\ & 318 & 600\end{array}$

* This value is quoted as $307 \mathrm{~nm}$ by Stiefel (1977) which appears to be an error (Aymonino et al. 1969; Wedd, unpublished observations) and $316 \mathrm{~nm}$ has been used for the calculations described in this paper.

Table 2. Constitution of thiomolybdate solutions derived from potassium tetrathiomolybdate*

Molybdenum concentration

(M)

$\begin{array}{ccc}\text { pH } & \overbrace{\text { Initial } \dagger} & \text { Derived } \ddagger \\ 6.6 & 0.99 \times 10^{-8} & 1.00 \times 10^{-8} \\ & 1.10 \times 10^{-4} & 1.09 \times 10^{-4} \\ & 2.41 \times 10^{-8} & 2.63 \times 10^{-8} \\ 7.6 & 1.03 \times 10^{-8} & 1.03 \times 10^{-8} \\ & 1.00 \times 10^{-4} & 0.97 \times 10^{-6} \\ & 2.51 \times 10^{-8} & 2.71 \times 10^{-8}\end{array}$

$\left[\mathrm{MoO}_{4-n} \mathrm{~S}_{n}\right]^{2-}$ concentration (M), for $n$ values of

\begin{tabular}{ccc}
\hline$n=4$ & $n=3$ & $n=2$ \\
$6.76 \times 10^{-4}$ & $2.67 \times 10^{-4}$ & $5.90 \times 10^{-5}$ \\
$7.42 \times 10^{-6}$ & $2.82 \times 10^{-6}$ & $6.22 \times 10^{-6}$ \\
$1.78 \times 10^{-6}$ & $7.03 \times 10^{-6}$ & $1.95 \times 10^{-6}$ \\
$7.04 \times 10^{-4}$ & $2.84 \times 10^{-6}$ & $4.30 \times 10^{-8}$ \\
$6.64 \times 10^{-6}$ & $2.53 \times 10^{-6}$ & $5.63 \times 10^{-6}$ \\
$1.79 \times 10^{-6}$ & $6.59 \times 10^{-6}$ & $2.56 \times 10^{-6}$
\end{tabular}

Free

sulphide concentration

(M)§

$$
\begin{aligned}
& 3.85 \times 10^{-4} \\
& 4.06 \times 10^{-5} \\
& 1.09 \times 10^{-8} \\
& 3.70 \times 10^{-4} \\
& 3.67 \times 10^{-5} \\
& 1.17 \times 10^{-6}
\end{aligned}
$$

* For the experimental conditions see p. 403.

The major source of error is the (undefined) uncertainty in the electronic spectral absorption maxima wavelengths and extinction coefficients (see Table I). No attempt has been made to present the results in the more general equilibrium constant format due to the difficulty in defining the exact concentrations of $\mathrm{H}_{2} \mathrm{~S}$ and [HS] $]^{-}$arising from the volatility of $\mathrm{H}_{8} \mathrm{~S}$.

+ Calculated from the mass of $\mathrm{K}_{2}\left[\mathrm{MoS}_{4}\right]$ used.

¥ Sum of the derived $\left[\mathrm{MoO}_{4-n} \mathrm{~S}_{n}\right]^{2-}$ concentrations.

Estimated from the derived $\left[\mathrm{MoO}_{4-n} \mathrm{~S}_{n}\right]^{\mathrm{a}-}(n=3,2)$ concentrations, assuming all the sulphide is in the solution phase.

determined under basic conditions (see Stiefel, 1977 ) and it is assumed that these are $\mathrm{pH}$ independent: the present results in fact confirm that thiomolybdates are weak bases.

\section{RESULTS AND DISCUSSION}

All thiomolybdate solutions generated in the present study by dissolution of $\mathrm{K}_{2}\left[\mathrm{MoS}_{4}\right]$, exhibited absorption maxima at 467, 395 and $316 \mathrm{~nm}$. Assuming Beer's Law, absorbance measurements at these three wavelengths allowed interpretation of the initially observed spectra in terms of the presence of the three thiomolybdate species $\left[\mathrm{MoS}_{4}\right]^{2-},\left[\mathrm{MoOS}_{3}\right]^{2-}$ and $\left[\mathrm{MOO}_{2} \mathrm{~S}_{2}\right]^{2-}(\mathrm{Table} 2)$. The relative proportions of the three thiomolybdate species remained essentially constant over the molybdenum concentration range of $10^{-3} \mathrm{M}$ to $2 \times 10^{-5} \mathrm{M}$. These proportions were $67 \pm 1 \%\left[\mathrm{MoS}_{4}\right]^{2-}, 26 \pm \mathrm{I} \%\left[\mathrm{MoOS}_{3}\right]^{2-}$ and $6 \pm 2 \%$ $\left[\mathrm{MoO}_{2} \mathrm{~S}_{2}\right]^{2-}$. Within experimental error, the total derived Mo concentration of these three species closely approximated that calculated from the initial mass of $\mathrm{K}_{2}\left[\mathrm{MoS}_{4}\right]$ used. Therefore, although the ion $\left[\mathrm{MoO}_{3} \mathrm{~S}\right]^{2-}$ also absorbs at $394 \mathrm{~nm}$ (Stiefel, 1977), it was unnecessary to assume either its presence or that of $\left[\mathrm{MoO}_{4}\right]^{2-}$ in the present study.

In the $\mathrm{pH}$ range $5-9$, the hydrolysis of $\left[\mathrm{MoS}_{4}\right]^{2-}$ in phosphate buffer or unbuffered 
solution reached equilibrium within $2 \mathrm{~min}$ of dissolution. The Mo species present at equilibrium (Table 2) were independent of both the solution $\mathrm{pH}$ (within experimental error) and the presence or absence of buffer. In reaching this equilibrium, sulphide (approximately $10 \mathrm{~mol}$ per cent) is liberated and in sealed vessels would be present essentially as [HS $]^{-}$and $\mathrm{H}_{2} \mathrm{~S}$ (the first and second acid dissociation constants of $\mathrm{H}_{2} \mathrm{~S}$ are $\mathrm{I}^{\circ} 6 \times \mathrm{IO}^{-7}$ and $4.0 \times 10^{-13}$ respectively (Freiser \& Fernando, I963)). In unbuffered solutions, the $\mathrm{pH}$ took some hours to stabilize, apparently while the liberated $\mathrm{H}_{2} \mathrm{~S}$ equilibrated between the solution and vapour phases.

Unbuffered hydrolysed solutions were stable in sealed vessels for at least $3 \mathrm{~d}$. However, in incompletely sealed containers, $\mathrm{H}_{2} \mathrm{~S}$ was gradually lost, the solution eventually became colourless and presumably molybdate was the final product. All solutions of $0.2 \mathrm{M}$-phosphate buffer bleached slowly (half-life in the order of days), apparently due to the substitution of sulphide by phosphate species.

The results to date show that tetrathiomolybdate $\left[\mathrm{MoS}_{4}\right]^{2-}$ (and assuredly the other thiomolybdates $\left.\left[\mathrm{MoO}_{4-n} \mathrm{~S}_{n}\right]^{2-}(n=3,2, \mathrm{I})\right)$ is a reactive species under the conditions outlined previously. These conditions are close to physiological in terms of Mo, acid and phosphate concentrations. However, the complex nature of the rumen alone warrants a detailed investigation of the stability and reactivity of these compounds in vivo if they are to be implicated in the $\mathrm{Mo}$ antagonism of $\mathrm{Cu}$.

In particular, the response of sheep to treatment with aqueous solution of, for example, tetrathiomolybdate, will be a result of the presence of the species: $\left[\mathrm{MoS}_{4}\right]^{2-},\left[\mathrm{MoOS}_{3}\right]^{2-}$, $\left[\mathrm{MoO}_{2} \mathrm{~S}_{2}\right]^{2-}$, [HS] $]^{-}$and $\mathrm{H}_{2} \mathrm{~S}$. Hence it is possible that thiomolybdate is acting merely as a source of sulphide or molybdate or both to the animal, and when the effect of thiomolybdate on $\mathrm{Cu}$ metabolism is being examined the contribution of these species must be recognized. Further, since thiomolybdates are unstable in air, special precautions should be taken to ensure that consistent storage and administrative procedures are adopted for sequential experiments; otherwise solutions of varying [HS]- and $\mathrm{H}_{2} \mathrm{~S}$ composition may be administered.

The authors thank the Rural Credits Development fund of the Reserve Bank of Australia for financial support for this work.

\section{REFERENCES}

Aymonino, P. J., Ranade, A. C., Diemann, E. \& Müller, A. (1969). Z. anorg. allg. Chem. 37r, pp. 295, 300.

Dick, A. T. (1953). Aust. vet. J. 29, I8.

Dick, A. T., Dewey, D. W. \& Gawthorne, J. M. (1975). J. agric. Sci., Camb. 85, 567.

Dowdy, R. P. \& Matrone, G. (1968). J. Nutr. 95, I9I.

Freiser, H. \& Fernando, Q. (1963). Ionic Equilibria in Analytical Chemistry. New York: J. Wiley \& Sons.

Gawthorne, J. M. \& Nader, C. J. (1976). Br. J. Nutr. 35, I I.

Krüss, G. (1884). Justus Liebigs Annln Chem. 225, I.

Mills, C. F. (1960). Proc. Nutr. Soc. 19, 162.

Stiefel, E. I. (1977). In Prog. inorg. Chem. 22, I. [S. J. Lippard, editor]. New York: J. Wiley \& Sons.

Suttle, N. F. (1974a). Proc. Nutr. Soc. 33, 299.

Suttle, N. F. (1974b). Br. J. Nutr. 32, 559.

Weber, K. M., Boston, R. C. \& Leaver, D. D. (1976). Proc. SIMSIG '76, Simulation Conference, Melbourne, p. 38 . 